\title{
Misericórdia na vida Cristã da lgreja: traços do Livro de Walter Kasper sobre a Misericórdia com luzes na catequese do Papa Francisco
}

Orientadora: Maria Teresa de Freitas Cardoso

Mestrando: Luiz Fernando Lima Rangel

Área de Concentração: Teologia Sistemático-Pastoral

Linha de Pesquisa: Religião e Modernidade

O tema da misericórdia é estudado a partir do que é apresentado no Livro de Walter Kasper "A Misericórdia - Condição fundamental do Evangelho e chave da vida Cristã”, com elementos para o aprofundamento do conhecimento da misericórdia de Deus, nas Escrituras, no ensinamento e na vida da Igreja, e sua ação dentro da Igreja e no mundo. Juntamente com o estudo de Kasper, a dissertação procura verificar o ensinamento do Papa Francisco no ano do Jubileu Extraordinário da Misericórdia. A dissertação destaca elementos do livro de Kasper e ênfases do ensinamento do Papa Francisco, em principais documentos pontífícios no ano jubilar, como a Bula Misericordiae Vultus que abre o ano da misericórdia e a carta apostólica Mirecordie et Misera fechando o ano e em audiências. Em Kasper e em Francisco apresentam-se questões importantes para o agir do cristão no mundo. A Escritura mostra a misericórdia de Deus. A misericórdia está na obra salvífica de Deus. A misericórdia deve estar na fé e na vida dos cristãos. O diálogo da misericórdia será necessário para levar a ação da misericórdia de Deus para uma cultura da misericórdia e para a evangelização do mundo. A Igreja deve receber a misericórdia de Deus e anunciar com palavras e obras da misericórdia e nos sacramentos. É necessário ter atenção com o sacramento da reconciliação onde a pessoa se encontra com o perdão e a misericórdia de Deus.

Palavras-chave: Misericórdia. Papa Francisco. Walter Kasper. Jubileu da misericórdia. Fé cristã. Vida cristã. Cultura da misericórdia. Diálogo da misericórdia. Obras de misericórdia. Sacramento de reconciliação. 